Violeta Vujković ${ }^{1}$

DOI: 10.31902/LL.2019.6.1.4

\title{
THE CONCEPTUAL METAPHOR WOMAN IS AN ANIMAL IN MONTENEGRIN WEBPAGES
}

\begin{abstract}
Animals are both a common and convenient source of conceptualising and constructing metaphors related to humankind in general, and, consequently, women in particular. Thus, women's behaviour and characteristics are often described by using the words and phrases which are used to describe animals (Kövecses, 2010). This paper investigates the three most commonly used realizations of the conceptual metaphor WOMAN IS AN ANIMAL in the Montenegrin webpages (the .me domain). The paper also deals with the context in which these metaphors typically occur, as well as with the ideological values they convey, which are both positive and negative in terms of presenting women's behaviour and beauty.
\end{abstract}

Key Words: conceptual metaphor, animal metaphor, women, animals, Montenegrin internet discourse

\section{Introduction}

This piece of research rests on the Conceptual Metaphor Theory, as established by Lakoff and Johnson (1980). The authors state that metaphor is deeply embedded in our way of conceptualising the world, and that metaphors are realized in speech through various linguistic expressions reflecting these conceptualizations.

The conceptual metaphor is a mental mechanism that helps us understand and organize reality. Abstract, complex and foreign concepts are simplified and reduced to familiar experiences through conceptual metaphors (Lakoff and Johnson, 1980). Sometimes, even domains that seem to be simple and straightforward can also be conceptualized through other domains.

When it comes to animal metaphors, Kövecses (2002) points out that they can be put as follows: PEOPLE ARE ANIMALS and HUMAN BEHAVIOUR IS ANIMAL BEHAVIOUR. He also argues that this type of metaphors is used in numerous languages to describe people and their behaviour. Thus, when exploring the linguistic expressions that are the embodiments of this metaphor, we address a very important topic and

${ }^{1}$ Master's student at the Faculty of Philology, University of Montenegro. 
come to insights that concern not only language, but also human thinking.

Women can be conceptualised in many ways (Perović, 2017), e.g. as food (cookie, honey, sugar), plants (rose, flower), animals (pussy, chicken, fish), means of transport (plane, ferrari), etc. This paper deals with the three most common realizations of the conceptual metaphor WOMAN IS AN ANIMAL in the Montenegrin webpages, i.e. the webpages having the .me domain.

In the first part of the paper, we will provide the theoretical background on which the present paper relies. We will introduce the Conceptual Metaphor Theory in detail and briefly outline the study of the conceptual metaphor WOMAN IS AN ANIMAL across languages. After the methodological part, we will introduce our analysis and draw the corresponding conclusions.

\section{Theoretical Framework}

As previously mentioned, the theoretical framework on which the present study relies is derived from the Conceptual Metaphor Theory, developed by Lakoff and Johnson in their well-known book Metaphors We Live By (1980). The mechanism of the conceptual metaphor is based on understanding the structure of one conceptual domain in terms of another one. The source domain is the domain from which we draw metaphorical expressions, and the target domain is the one that we try to understand. Source domains are usually: parts of human body, plants, animals, food, drink, games, sports, money, machines and tools, forces - entities that we are familiar with and that are concrete. Typical target domains include: emotions, society, politics, time, religion, life, human relationships (love, friendship, marriage), moral categories (honesty, courage, honour), and other abstract concepts (Kövecses, 2002; Klikovac, 2004).

Various things, concepts, ideas and situations are subject to metaphorical conceptualisation. For example, life is often regarded as a journey and we can often hear people say (He is at the crossroads of life; He left this world; She is on the right path, etc). These are just some of the many realizations of the conceptual metaphor LIFE IS A JOURNEY (Lakoff and Johnson, 1980).

In their book, Lakoff and Johnson (1980) point out that our conceptual system is fundamentally metaphorical. To illustrate this, they use the conceptual metaphor ARGUMENT IS WAR with the following linguistic realizations: Your claims are unbeatable; He attacked every weak point of my argument; His words hurt me, etc.

The concepts of women and men are also frequently metaphorized. Perović (2017) cites the following metaphorical 
conceptualisations of women in Montenegrin: WOMAN IS A PLANT (ona cvjeta (translation: she blooms)), WOMAN IS AN ANIMAL (ona je lavica (trans. she is a lioness)), WOMAN IS A PLANT (ona je ruža (trans. she is a rose)), WOMAN IS A SUBSTANCE (ona je otrov (trans. she is poison)), etc.

Our paper is concerned with the conceptual metaphor WOMAN IS AN ANIMAL and its realizations in the Montenegrin webpages. Our study, conducted following the methodology provided after the literature review below, showed that the three most common animal metaphors used to conceptualize women in the Montenegrin webpages were ŽENA JE MAČKA (WOMAN IS A CAT), ŽENA JE RIBA (WOMAN IS FISH) and ŽENA JE LAVICA (WOMAN IS A LIONESS). These metaphors were used to represent both positive and negative characteristics of women's behaviour and physical appearance.

\section{Metaphorical conceptualisation of women across cultures}

Some aspects of the conceptual metaphor WOMAN IS AN ANIMAL have been the subject of interest of several authors when it comes to the English language; despite this interest, a systematic overview of this metaphor has not been provided in the literature, to our best knowledge.

On the other hand, very few studies of conceptual metaphor in general have been conducted in Montenegro. To our best knowledge, only two of these deal with the metaphors depicting women - one conducted by Bratić and Vuković Stamatović (2017), who dealt with the metaphor WOMAN AS A CAR in Bosnian/Croatian/Montenegrin/Serbian, and another, more general one, carried out by Perović (2017), who touched on how women are represented as animals in Montenegro, although not much attention was devoted to this issue, bearing in mind the more general goals of her study. Perović (2017) noticed that people often conceptualise women as small or big animals. For example, realizations of the conceptual metaphor WOMAN IS A SMALL ANIMAL include pile (chick) and mače (kitten), whereas the realizations of the metaphor WOMAN IS A BIG ANIMAL would be krava (cow), lavica (lioness), etc.

Silaški (2011) cited the following animals used within the conceptual metaphor WOMAN IS AN ANIMAL to depict women in the Serbian language: mačka (cat), guska (goose), patka (duck), lavica (lioness), etc. As was the case with Perović (2017), the data for this piece of research were also collected via a questionnaire.

In the study presented here, we depart from a premise that employing a corpus-based approach would enable a more comprehensive and detailed analysis, as we will deal with the linguistic realizations of the metaphors in authentic texts. 
Rešetar and Radić (2003) also conducted a study in which they pointed out that animal names were more commonly used as a means of insult in the conceptualisation of women in the Serbian language. To purport their conclusion, they discussed the following metaphors: WOMAN IS A EWE, WOMAN IS A COW, WOMAN IS A SOW, etc. The authors also dealt with the ideological aspects of such metaphorizations.

Milić (2013) categorised animals used to conceptualise a woman and stated that those were usually domestic animals, cattle or poultry. The most common animal metaphors in his study were found to be WOMAN IS A CROW and WOMAN IS A HEN.

Silaški and Kilyeni (2015) dealt with a contrastive cognitivelinguistic analysis of the metaphor WOMAN IS AN ANIMAL in Serbian and Romanian. They came to the conclusion that similar expressions were used in both these cultures to express positive or negative characteristics of women. For example, the lioness was chosen by the male respondents in both the cultures as a domain that they use to refer to a strong, ambitious, persistent, confident and self-sacrificing woman.

Hines (1999) identified the conceptual metaphor WOMAN IS A PREDATORY ANIMAL in English, which was realised through the submetaphors such as WOMAN IS A LIONESS and WOMAN IS A COUGAR.

Rodriguez (2009) also dealt with the study of animal metaphors in English. In her research, she pointed out that, by the use of animal metaphors, women were usually presented as small and helpless animals, whose main purpose was to provide entertainment and food. She also pointed out that animal metaphors were almost always used to express people's negative characteristics. She cited the metaphor WOMAN IS A CAT as an example, and pointed out that in English CAT stands for a malicious woman or a prostitute.

Kövecses (2006) assumes that the conceptualisation of a WOMAN AS A BIRD is probably universal and that this metaphor is most likely based on the perceived similarity between these feathered animals and the female genital organs (hair, softness, fluffiness).

To summarize, different authors have addressed some aspects of this topic. Our goal here is to deal with the three most common realizations of the conceptual metaphor WOMAN IS AN ANIMAL in the Montenegrin webpages by using a corpus approach as opposed to almost all of the studies reported above, as well as to critically analyse the obtained results.

\section{Methodology}

The conceptual metaphors analysed in this paper were gathered from various Montenegrin webpages (the .me web-domain). At the very beginning of this study, we used the source domain vocabulary 
extraction method. Metaphorical expressions always contain lexical units from their source domain, so it is reasonable to begin research by selecting a potential source domain (Stefanowitsch and Gries, 2006). For the purpose of this piece of research, these were animal names, as well as verbs which are related to animal behavior. Here we applied the Metaphorical Pattern Analysis (MPA), established by Anatol Stefanowitsch (2006). When searching for the realizations of the animal metaphor WOMAN IS A CAT, we searched through various Montenegrin webpages using the search criteria such as "woman * a real cat", "look at * pussycat", "she * kitten" and similar expressions. In the same way, the search was conducted for the other two realizations of the general metaphor WOMAN IS AN ANIMAL in the corpus of the Montenegrin webpages.

We then applied the method of identifying conceptual metaphors. For the purpose of this study, we used the procedure for identifying metaphorical language in the real discourse - the Metaphor Identification Procedure (MIP) (Pragglejaz Group, 2007). The aim of this procedure is to determine whether the use of the lexical units in a particular context can be described as metaphorical or not (Steen, 2002). First, we read the excerpts obtained by using the Metaphorical Pattern Analysis method (MPA), in order to gain a general understanding of the meaning. Then, we identified the lexical units, as well as determined the contextual meanings for each of them. After that, for each lexical unit, we determined whether they conveyed a meaning in other contexts that differed from the one in our corpus. During the process of identifying conceptual metaphors, we identified various realizations of the animal metaphors used to conceptualise a woman.

After identifying and extracting the conceptual metaphor realizations from the corpus, we proceeded to the analysis of the data. We analyzed the three animal metaphors that were most commonly used in the Montenegrin webpages. Those were the following metaphors: WOMAN IS A CAT, WOMAN IS FISH and WOMAN IS A LIONESS.

\section{Results and discussion}

While searching through different Montenegrin webpages, we came across numerous realizations of the animal metaphor WOMAN IS AN ANIMAL. Some of them were used to express the positive characteristics of women's behavior and beauty, and some to highlight the negative ones.

The animal metaphor that is most commonly used in the Montenegrin webpages is the metaphor ŽENA JE MAČKA (WOMAN IS A CAT) - we came across 21 realizations of this metaphor in the said 
corpus. On various Montenegrin webpages, we found metaphorical realizations comparing women to cats. Here, we will present some of them:

1) "Maite Peroni je prava mačka." (Prva.me)

["Maite Peroni is a real kitty."]

2) "Mnogo si seksi, lepa, zgodna, Hrvatska objašnjava. Sve žene iz Hrvatske su opasne mačke i to mi se jako sviđa.", rekla je Jelena." (Grand. online)

["You are very sexy, beautiful and pretty, Croatia explains everything. All women from Croatia are dangerous cats and I really like that, said Jelena."]

3) "Kakva mačka: Ova lepotica teši Del Potra posle poraza od Đokovića!" (Naslovi.net)

["What a kitty: This beauty comforts Del Potro after his defeat from Đoković!"]

4) "Vidi mačkice", pogledom mu pokažem na separe preko puta nas. (Wattpad.com)

["Look at that kitten,' my look directs him to the booth across our own."]

According to the results obtained, we can conclude that the users of the Montenegrin webpages use various realizations of the conceptual metaphor WOMAN IS A CAT in order to present the positive characteristics of female beauty, especially those concerning female physical appearance. Using these metaphorical expressions, speakers want to emphasize how beautiful, attractive and seductive the woman described is. Based on these excerpts, we can conclude that the users posting on Montenegrin webpages used the metaphor WOMAN IS A CAT in a positive context, in order to emphasize the beauty and attractiveness of women.

Our study also reveals that in most cases men use realizations of the conceptual metaphor WOMAN IS A CAT when addressing women directly. In four out of five examples where direct addressing is present, the users of the metaphor are men.

In order to find as many realizations as possible, we included verbs which describe cats' behaviour in our search criteria. The search results showed that the users of Montenegrin webpages often describe female behaviour using verbs which are used to describe cats' behaviour. The following excerpt supports this: 
5) "... tada sikčem, grebem, grizem, branim. Približim se $i$ zapredem samo osobama od povjerenja, od ostalih se manim $i$ zatvorim se u svoje psihološke kartonske kutije iz kojih ne izađem toliko često, a kamoli da provirim kroz koju rupicu. Ne znam je li to zbog toga što sam im zgodna, zbog toga što pomazim i nakon toga lagano ogrebem, što ugrizem druge umjesto svoj jezik kad nije vrijeme za reći određene stvari." (Blog. dnevnik)

["... then I hiss, scratch, bite, defend myself. I approach and purr only before the people I trust, I shy away from the others, and close myself into my psychological cardboard boxes from which I don't get out as often, let alone peek through the holes. I do not know if it is because they find me pretty, or because I cuddle first and afterwards gently scratch, that I bite others instead of hold my tongue when it is not time to say certain things."]

Excerpt 5 points to the conclusion that women sometimes compare themselves to cats and that they use verbs that are characteristic of cats' behavior to describe themselves and their actions. In this example, those are the following verbs: 'hiss', 'scratch', 'bite', 'purr', and 'cuddle'. The first three verbs are used to describe cats' behaviour when in danger, when defending their territory or prey. Montenegrins sometimes describe angry or moody women, or those under threat, in these terms (hissing, scratching, biting). Thus, Montenegrins use the conceptual metaphor WOMAN IS A CAT when they want to refer to a strong woman who is ready to do anything to protect herself and her own.

Based on the aforementioned realizations, we can infer that, in the Montenegrin culture, women are often conceptualised via the animal metaphor WOMAN IS A CAT. The users of the Montenegrin webpages do not use this conceptual metaphor to convey ideological values that are negative for representing female behaviour, but to depict a pretty, attractive and seductive woman, or a woman who is strong, combative and self-confident.

The animal metaphor which was also very frequent in the Montenegrin internet webpages is the metaphor ŽENA JE RIBA (WOMAN IS FISH). The search conducted applying the said criteria resulted in 18 realizations of this metaphor. In everyday speech, we can often hear people using riba (fish) to address a girl or a woman. Borivoj and Nataša Gerzić (2002) point out that the discourse in which this metaphor is used is androcentric and that it is produced by two cognitive-linguistic mechanisms: "By metaphorical transmission, the fish becomes a mark for the female genital organ through the seme of humidity and the fish's mouth (the female genital organ is fish) and then, 
by metonymy, it becomes the name for the female person (the woman is the female genital organ)" (Gerzić and Gerzić, 2002).

On various Montenegrin webpages we came across the following realizations of the said metaphor:

6) “Muškarci su srećni samo ako im je žena dobra riba. Ljepota je muškarcima presudna za uspješan brak, pokazala su najnovija američka istraživanja. Muževi koji pored sebe imaju privlačne supruge imaju duže i srećnije brakove, a što je najvažnije, to zadovoljstvo ne nestaje sa godinama prenosi CDM." (Kodex.me) ["Men are happy only if their wife is good fish. Beauty is crucial to a successful marriage for men, according to the latest American research. Husbands who have attractive wives next to them have longer and happier marriages, and most importantly, that satisfaction does not disappear with age, CDM reports. "]

7) “Ana Nikolić, koja će se uskoro poroditi, ovako se šali na sopstveni račun! "Svesna sam toga da više nisam dobra riba. $U$ trudnoći se telo promeni, ali mi lice nekako izgleda lepše kažu da trudnice zrače unutrašnjom lepotom," rekla je ona." (Mondo.me) ["Ana Nikolić, who is about to give birth, is joking like this at her own expense! "I am aware that I am no longer good fish. In pregnancy, the body changes, but my face somehow looks more beautiful now, they say that pregnant women radiate inner beauty, she said."]

The conceptual metaphor WOMAN IS FISH carries a positive evaluation of women's appearance. The phrase ona je riba (she is fish) has the meaning: she is a beautiful woman. This can be seen from the following excerpts:

8) "Pojavila se kao buca na audiciji ZG, a danas je najbolja riba na estradi: Ne možete ni da pretpostavite koja pjevačica je u pitanju! Danas je jedna od najuspješnijih poznatih ličnosti, svi govore da je "mega dobra riba", u pitanju je Milica Pavlović koja se s godinama prilično promijenila i postigla veliki uspjeh na javnoj sceni." (Staging.montenegroclick.me)

["She appeared as a pudge at the ZG audition, and today she is the best fish in show business: You can't even guess which singer is at stake! Today, she is one of the most successful celebrities, everyone says she is 'mega good fish', it is Milica Pavlović who has changed quite a bit over the years and achieved great success on the public stage."] 
9) "Pokušala sam da ti nađem neku manu, pa sam razmišljala kako si sad tako prelijepa, ali da ćeš možda ružno da ostariš i da nećeš biti dobra riba." (Sarajevograd.me)

["I tried to find you some flaw, so I was thinking if you were so beautiful now, maybe you would not be such good fish when you get old."]

Our study reveals that riba (fish) is used to characterise a woman with a beautiful body, who typically shows it off using attractive, sexy clothes. This is corroborated by the words and phrases which co-occur in the above-mentioned excerpts: attractive (1), more beautiful, beauty (2) and beautiful (4). All these words serve to better illustrate the appearance of a woman. This metaphor emphasizes the physical appearance of a woman but backgrounds her other characteristics.

We also came across excerpts in which women use riba ('fish') to refer to themselves:

10) "Šta da radim, kad sam dobra riba. Kortni Stoden uživa da počasti svoje fanove fotografijama na Twitteru." (Mondo.me)

["What Can I Do When I'm Good Fish. Courtney Stoden enjoys treating her fans with photos on Twitter."]

11. "Seka Sablić: Željela sam da igram zavodnice, ali nisam bila dobra riba. Nikad nijesam dobila ulogu zavodnice. Sad kad pogledam svoje stare snimke i slike, pomislim - Bože, što sam bila dobra riba." (Cdm.me)

["Seka Sablić: I wanted to play the role of a seductress, but I wasn't good fish. I never got the role of a seductress. Now, when I look at my old shots and pictures, I think - God, I was good fish."]

Although the literature argues that the metaphor WOMAN IS FISH is used to refer to a woman in a negative way, our study pointed to the conclusion that riba (fish), used for referring to a woman, is used to metaphorically represent an attractive woman, a woman who is perceived as desirable.

However, we also came across a different view of what riba (fish) means:

12. "Biti dobra riba ne znači imati određene dimenzije tijela. Naprotiv, znači voljeti sebe, uživati u sebi, biti sebi lijepa bez obzira na proporcije." (Chiwelook.me) 
["Being good fish does not mean having certain body dimensions. On the contrary, it means loving yourself, enjoying yourself, being beautiful reagrdless of the proportions."]

13. "Dobra riba nije tek bilo koja lepa devojka, ima lepih žena koje su veći deo svog života provele sakrivene i neprimetne. Dobra riba je uvek bila i ostala ona za kojom većina muškaraca žudi. Dobra riba je uvek zgodna ali ne sećaš se da li ima plave oči, zelene ili crne. Kada ona uđe u sobu svi je osete, atmosfera sobe se promeni, svi se naglo osete uzbuđeno i muškarci i žene."

(Gradimozivot.wordpress.com)

["Good fish is not just any pretty girl, there are many beautiful women who have spent most of their lives hidden and unnoticed. Good fish has always been and remained the one most men crave. Good fish is always pretty, but you don't remember if her eyes are blue, green or black. When she enters the room, everyone feels her, the atmosphere in the room changes, everyone suddenly feels excited, both men and women."]

From the two excerpts above, we can conclude that their authors were women. According to them, in addition to her breathtaking physical appearance, riba (fish) refers to a woman which must be selfconfident. She is a woman whom men crave, shrouded in mystery, not easily conquered.

We noticed that various realizations of the metaphor WOMAN IS FISH are often used to conceptualise famous women. Those women are thought to have perfectly shaped bodies, representing the ideal of feminine beauty.

Based on the realizations presented above, we can deduce that the users of the Montenegrin webpages often use the metaphor WOMAN IS FISH to conceptualize women. This metaphor foregrounds the physical appearance of a woman, while leaving all her other characteristics backgrounded.

The third conceptual metaphor that was fairly frequent in the Montenegrin webpages was the metaphor WOMAN IS A LIONESS. We found 14 realizations of this metaphor, which we will present and interpret below. Particular attention will be paid to the context in which certain metaphorical realizations are used.

The excerpts found point to the conclusion that Montenegrins posting in local webpages often use the metaphor WOMAN IS A LIONESS to depict single mothers who are trying hard to provide their children with a carefree childhood. The excerpts are presented below: 
14) "MAJKA LAVICA, ĆERKE ŠAMPIONKE: Prvo mjesto u Istanbulu za Podgoričanke sa Daunovim sindromom." (Pvinformer.me) ["Mother lioness, daughters champions: First place in Istanbul for the girls with the Down syndrome from Podgorica."]

15) “ŽENA LAVICA: Dragica OBUĆARSKIM ČEKIĆEM podigla troje djece!" (Volimpodgoricu.me)

["Woman Lioness: Dragica Raised Three Children thanks to a Shoe Hammer!"]

We also came across several realizations describing brave women and women who have a difficult life but never give up and fight until the end, as prave lavice (real lionesses). There were five such realizations, and some of them are presented below:

16) "PREŽIVELA SAM SVE, jer sam LAVICA, ali PRESKUPO me koštala LJUBAV sa tobom... , (Facebook.com)

["I survived everything because I'm a LIONESS, but LOVE with you cost me too much..., ,]

17) "Borit ću se kao lavica protiv svijeta koji me želi kontrolirati, ali ću te i voljeti. Kada se svijet okrene protiv mene, ja ću uzvratiti. la ću se boriti $i$ šakama i riječima i mišićima i srcem." (Pozitivanstav.com)

["I will fight like a lioness against the world that wants to control me, but I will also love you. When the world turns against me I will reciprocate. I will fight with my fists and words and my muscles and my heart."]

The excerpts point to the conclusion that the users posting on Montenegrin webpages use different realizations of the metaphor WOMAN IS A LIONESS when they want to refer to a woman who is strong, independent, fearless and who overcomes every problem in life. The phrase žena lavica (a woman lioness) was used to emphasize the sacrifice, renunciation and perseverance of single mothers, mothers who try hard to give their children a carefree childhood, women who had many difficulties in life but never gave up. Thus, this metaphor was used to describe a strong woman and the positive characteristics she possesses.

Our research reveals that women sometimes use lavica (lioness) when describing themselves. We came across two examples of this type. Realizations of the metaphor WOMAN IS A LIONESS are also used to describe celebrities. Four realizations of this type were found. 
Realizations of were also used to describe women who are not celebrities but ordinary women who became popular due to their life force and struggle for their family. We came across eight realizations of this type. The following expressions were dominant in those realizations:

18) "Boriću se kao lavica." (Pozitivanstav.com)

["I'll fight like a lioness."]

19) "Bila je lavica do kraja." (Www.rtvbn.com)

["She was a lioness to the end."]

20) "Kada diraju njenu djecu postaje prava lavica." (Pinkm.me)

["When they touch her children, she becomes a real lioness. "]

21) "Sa nevjerovatnom posvećenošću, hrabrošću i optimizmom korača kroz život - kao prava lavica." (Kalia.co.me)

["She walks through life with incredible dedication, courage and optimism - like a real lioness."]

All of these lexical words used in the realizations of the basic metaphor WOMAN IS A LIONESS serve to demonstrate how courageous and sacrificial the women in question are. Žena lavica (woman lioness) was presented as a true fighter who was not "pampered" by life, but who, despite all misfortunes, never gave up and continued fighting through life with optimism and courage.

\section{Conclusion}

This study revealed that the conceptual metaphors WOMAN IS A CAT, WOMAN IS FISH and WOMAN IS A LIONESS are most commonly used by the users posting on the Montenegrin webpages, when they refer to women as animals. These metaphors were used in order to convey ideological values which are both positive and negative for the representation of women's behaviour and beauty.

The conceptual metaphor WOMAN IS A CAT was used to depict a pretty, attractive and seductive woman, or a woman who is strong, combative and self-confident. Users posting on Montenegrin webpages use different realizations of the conceptual metafor WOMAN IS FISH to represent an attractive woman, a woman who is perceived as desirable. Our study revealed that this metaphor foregrounds the physical appearance of a woman, while leaving all her other characteristics backgrounded. Finally, the conceptual metaphor WOMAN IS A LIONESS was used to refer to a woman who is strong, independent, fearless and 
who overcomes every problem in life. In our study, we came across different realizations of this metaphor which were used to describe both celebrities and ordinary women who became popular due to their life sacrifice and struggle for their family.

We hope that with this study we contributed to the research of the conceptual metaphor in the Montenegrin language, in particular, and to the studies on the conceptualization of women across cultures, in general.

\section{References}

Barasa, Margaret. "The Use Animal Metaphors in the Representation of Women in Bukusu and Gusii Proverbs in Kenya“. Africology: The Journal of Pan African Studies. Kisii: Kisii University, 2017, 9-28.

Bratić, Vesna, and Milica Vuković Stamatović. "Commodification of women through conceptual metaphors: the metaphor woman as a car in the western Balkans." Gender \& Language 11.1 (2017): 51-76.

Dragićević, Rajna. Semantička proučavanja srpskog jezika. Beograd: SANU, 2008.

Gerzić, Borivoj, i Nataša Gerzić. Rečnik savremenog beogradskog žargona. Beograd: SANU, 2002.

Halupka-Rešetar, Sabina, and Biljana Radić. "Animal Names Used in Addressing People in Serbian”. Journal of Pragmatics 35 (2003): 1891-1902.

Hines, Caitlin. "Foxy chicks and Playboy bunnies: A case study in metaphorical lexicalization". Cultural, Typological and Psychological Perspectives on Cognitive Linguistics 9 (1999): 9-24.

Ivić, Milka. Pravci u lingvistici. Beograd: Biblioteka XX vek, 2001.

Kövecses, Zoltán. Metaphors of Anger, Pride, and Love: A Lexical Approach tothe Study of Concepts. Amsterdam: John Benjamins, 1986.

Kövecses, Zoltán. The language of love: The Semantics of Passion in Conversational English. Lewisburg, Pa.: Bucknell University Press, 1988.

Kövecses, Zoltán. Metaphor in Culture: Universality and Variation. Cambridge: Cambridge University Press, 2005.

Kövecses, Zoltán. Language, Mind and Culture. New York: Oxford University Press, 2006.

Kövecses, Zoltán. Metaphor: A Practical Introduction. Oxford: Oxford University Press, 2010.

Lakoff, George. The Contemporary Theory of Metaphor. Chicago: Chicago University Press, 1993.

Lakoff, George, and Mark Johnson. Metaphors We Live by. Chicago and London. The University of Chicago Press, 1980.

Langacker, Ronald. Foundation of Cognitive Grammar. Vol I: Theoretical Prerequisites. Stanford, California: Stanford University Press, 1987.

Milić, Goran. „Pristup zoosemiji u okviru teorije konceptualne metafore i metonimije“. Jezikoslovlje 14.1 (2013): 197-213.

Pragglejaz Group. "MIP: A Method for Identifying Metaphorically Used Words in Discourse“. Metaphor and Symbol, 22(1) (2007): 1-39. 
Rodriguez, Irene. "Of women, bitches, chickens and vixens: animal metaphors for women in English and Spanish". Cultura, Lenguaje $y$ Representación/Culture, Language and Representation 7 (2009): 77 100.

Silaški, Nadežda. "Animal Metaphors in Some Business-Related Terms in English". Radovi Filozofskog fakulteta u Istočnom Sarajevu 13(1) (2011): 565-575.

Silaški, Nadežda, and Annamaria Kilyeni. "Animal Metaphors and Semantic Derogation - Do Women Think Differently From Men?". Versita (2015): 319-325.

Perović, Slavica. Pojmovna metafora kulturno srodnih pojmova. Podgorica: Crnogorska Akademija Nauka i Umjetnosti, 2017.

Polovina, Vesna. Semantika i tekstlingvistika. Beograd: Čigoja, 1999.

Searle, John. Metaphor. Metaphor and Thought. Cambridge: Cambridge University Press, 1993.

Stanojević, Mateusz-Milan. Konceptualna metafora: Temeljni pojmovi, teorijski pristupi i metode. Izdanje Srednja Europa: Zagreb, 2013.

Stefanowitsch, Anatol, and Stefan Th. Gries. Corpus-Based Approaches to Metaphorand Metonymy. Berlin/New York: Mouton de Gruyter, 2006. 